\title{
Nutritional-Medicinal Profile and Quality Categorization of Fresh White Button Mushroom
}

\author{
Satish Kumar Sinha ${ }^{1 \mathbb{D}}$, Tarun Kumar Upadhyay ${ }^{1, * \mathbb{D}}$, Sushil Kumar Sharma ${ }^{1}$ \\ ${ }^{1}$ School of Agriculture, Suresh Gyan Vihar University, Jaipur, India \\ *Correspondence: tarun_bioinfo@yahoo.co.in; tarun.kumar@mygyanvihar.com;
}

Scopus Author ID 57193549427

Received: 8.07.2020; Revised: 31.07.2020; Accepted: 1.08.2020; Published: 2.08.2020

\begin{abstract}
Due to susceptible change era for the world, limited land resources; vast encounter to meet the food demand and medicine for the growing populations make the necessity to discover any alternative food which has good nutritional and medicinal value. Hence, the quality categorization of Fresh White Button Mushroom has been necessitated by the need for harmonizing requirements governing the quality of products. The contents and categorizations were formulated in accordance with the procedures established by standards physiochemical and sensory determination methods. The chemical composition (moisture, ash, protein, carbohydrate, total fat) and minerals composition (Se, $\mathrm{Ni}, \mathrm{Mn}, \mathrm{Cu}, \mathrm{Zn}, \mathrm{Na}, \mathrm{N}, \mathrm{Fe}, \mathrm{P}, \mathrm{Ca}, \mathrm{Mg}, \mathrm{S}$, and K) of white button mushroom were determined. Results

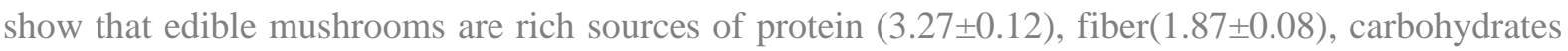
$(2.66 \pm 0.61)$, fats $(0.22 \pm 0.05)$ and energy $(28.50 \pm 1.22 \mathrm{Kcal}) \mathrm{g} / 100 \mathrm{~g}$ fresh weight basis respectively. In addition to these, white button mushrooms also contain the highest content of potassium ( $3560 \pm 153.33)$ and sulfur $(2195.59 \pm 1405.60) \mathrm{mg} / \mathrm{kg}$ fresh weight basis mineral elements. The quality categorization was monitored under a controlled environmental condition (Temp. $5-6 \pm 1^{\circ} \mathrm{C}$ ) and packed in a $30 \mu \mathrm{m}$ thickness polyethylene bag. The data were categorized by organoleptic, physicochemical, and bacterial count (CFU/g) basis. The grades SSQM: size $<33.44 \mathrm{~mm}$, whiteness(Hunter) $>80$ number of pieces: 19/200g, open veils; Nil, Veiled: Nil; lactic acid: > 0.7\%, Lactococcus lactis: >9.5x105,SQM: Size range of 33.57-38.55, whiteness (Hunter):70-80, Veiled 1, open veiled 1, open veiled 6.25\%, lactic acid: 0.4-0.7 \% and Lactococcus lactis: > $8.4 \times 10^{5}$, AQM: size>38.62, Whiteness (Hunter): 60-70,Veiled 1, open veiled 2, open veiled $16.6 \%$, lactic acid: $0.3-0.4 \%$ and Lactococcus lactis: $>3.4 \times 10^{5}$. The overall fruiting body has a significantly high level of nutrient and mineral composition, Lactic acid, and probiotic bacteria, thus WBM can be used as a good source of food as well as medicine.
\end{abstract}

Keywords: White Button Mushroom; Nutritional; Medicinal Profile; Lactic acid; Lactococcus lactis; Immunomodulation.

(C) 2020 by the authors. This article is an open-access article distributed under the terms and conditions of the Creative
Commons Attribution (CC BY) license (https://creativecommons.org/licenses/by/4.0/).

\section{Introduction}

The complete nutrition and diet are increasing very significantly, not just in the regular everyday life of human beings, but similarly in the treatment of chronic diseases and incessant infections. Worldwide specialists are identifying that mushrooms are restorative foods rich in nutrition. The therapeutic properties of WBM are effectively clinical trials conducting throughout the world by the National Institute of Health (NIH) and WHO. Mushrooms are an important natural source of food and medicine; in this way, FDA has formally chosen mushrooms as "healthy foods. Due to insufficient studies on the nutritional properties of wideranging mushrooms have been stated in the reports $[22,26]$. 
Mushrooms are a good source of vitamin B complex riboflavin (B2, niacin (B3), Pantothenic acid (B5), ergo sterols (provitamin D2) and minerals such as (selenium, potassium, and copper). Mushrooms additionally, also contains a wide range of therapeutic compounds such as triterpenoids, glycoproteins, natural antibiotics, enzymes, and enzyme inhibitors that strengthen the human health system [12]. Mushrooms contain nine fundamental amino acids like arginine, histidine, lysine, leucine, isoleucine, methionine, phenylalanine, threonine, and valine. Mushrooms are accepted everywhere throughout the world as valuable health foods since they are poor in calories, fat, and fundamental fatty acids and rich in protein, vitamins, and minerals [55]. WBM is considered to be next-generation health food supplements as they are low in fat, have no cholesterol, high in protein with good biological value, and identified as a food source to fight starvation in developing countries [27]. In addition, WBM contained a natural source of carbohydrates, unsaturated fatty acids, dietary fibers, vitamins and minerals, and low in heavy metals $[24,39,53,59,61,58,68]$. The post-harvest losses can make the quality and safety improvement by quality standards categorization of the WBM [50]. The quality categorization on the basis of sensory properties such as taste, texture, and flavor is distinctive properties of this fleshy and edible mushroom with regard to the consumer's point of view for sustaining a healthy life [20,21,53].In WBM, biologically active phytochemicals residing in this species are also significant interest from the pharmaceutical and nutraceutical aspects [17].

Mushroom used as a fresh ingredient in soup, sauces, salads, stuffing's and meat dishes $[6,10,14,15,19,48,76]$. The quality of WBM was also affected by various factors like transportation, processing, packaging, and storage. The classification method of quality of WBM, seems to be very real, easy to practice, and low-slung value, but not always a feasible approach for all mushroom species [1,2]. The basic nutritional profile of White button mushroom (WBM) on dry weight basis available in the previous study, but there are no such reports that are dealing with fresh white button mushroom with nutritional, therapeutic minerals elements and categorization with specific factors like size, whiteness (color) and bacteria. Therefore, the main aim of this study was to assess quantitative data on the basis of fresh WBM nutritional values; minerals content, bacterial load, and organoleptic changes occur during storage were analyzed and categorized for acceptance in dietary use.

\section{Materials and Methods}

\subsection{Study area.}

This research was carried out at Dr. Analytical laboratories, which is located in Navi Mumbai, Maharashtra-India. White button mushroom (A.bisporus) was collected from the mushroom cultivated farm, Pune, India. Dr. Analytical Laboratories, Navi Mumbai provides the entire chemicals and reagents of an analytical grade for the testing of samples.

\subsection{Experimental design.}

The WBM was collected for the study; as they can be reared easily and successfully in the existing climatic conditions and their importance as edible species, they have wider distribution. WBM cultivated under controlled conditions temperature ranging from $14-18^{0} \mathrm{C}$. The $2 \mathrm{~kg}$ fresh mushrooms were collected and analyzed for nutritional and medicinal value and quality categorization. 


\subsection{Methods for nutritional and mineral content.}

\subsubsection{Moisture Content.}

The quantum of moisture percentage of WBM was determined by drying the fresh wet mushroom. They were kept at $105 \pm 2{ }^{\circ} \mathrm{C}$ in an oven for 2 hours to dry. The sample was weighed about $5 \mathrm{gm}$ and placed in the formerly dried and tared moisture dish (about $75 \mathrm{~mm}$ wide and $25 \mathrm{~mm}$ deep). The dish was then transferred in an air oven and cooled in a desiccator and weigh. The process was repeated until the change between two consecutive weighings is less than 1 $\mathrm{mg}$, and finally, the lowest weight was recorded [29].

\subsubsection{Mineral Content.}

The carbon content in WBM was determined by the titration method. $0.05 \mathrm{~g}$ of the sample placed into $250 \mathrm{ml}$ volumetric flask and $25 \mathrm{ml}$ of potassium dichromate-sulphuric acid solution added, and the mixture was boiled at $200^{\circ} \mathrm{C}$ for 60 minutes, thereafter cooled at room temperature. The total volume of about $100 \mathrm{ml}$ was made with distilled water. After that 0.2 $\mathrm{mol} / \mathrm{l}$ ammonium Iron II sulfate solution was added until the brown color disappeared. $0.25 \mathrm{ml}$ of N-phenylanthranilic acid solution was added and titrated with $0.2 \mathrm{~mol} / \mathrm{l}$ ammonium iron II sulfate solution until the solution becomes blue-green [28]. Nitrogen estimation was carried out by a standard method [8]. The Selenium (Se), Nickel (Ni), Manganese (Mn), Copper (Cu), Zinc (Zn), Sodium (Na), Iron (Fe), Phosphorus (P), Calcium (Ca), Magnesium (Mg), Sulphur (S) and Potassium (K) were determined by standard methods [44].

\subsubsection{Protein Content.}

The nutritive value of protein content in the WBM was analyzed by the digestion method. In brief, $2.2 \mathrm{~g}$ samples were placed into digestion flask, and $0.7 \mathrm{~g}$ mercury oxide, $15 \mathrm{~g}$ powdered potassium sulfate, and $25 \mathrm{ml}$ sulphuric acid were added in a sequential manner. The flask was placed on a heater in an inclined position and warmed gently until foaming ceases. A small amount of paraffin added to reduce foaming, and the solution was boiled vigorously until the solution became clear for almost 2 hours. After cool down the solution, $200 \mathrm{ml}$ of distilled water was added, and mercury was precipitated by adding $25 \mathrm{ml}$ of the thiosulphate solution. $\mathrm{Zn}$ granules were added to avoid jerking, and $25 \mathrm{~g}$ of $\mathrm{NaOH}$ (solid pellet) was added to make the solution strongly alkaline. The flask was then connected to the distillation bulb on the condenser, and the flask was rotated to mix the content thoroughly and heated immediately until the ammonia has distilled over $(150 \mathrm{ml})$. Excess acid was titrated with standard $(0.1 \mathrm{~N}$ $\mathrm{NaOH}$ ) using methyl red as an indicator. Blank was also determined using all reagents and calculated protein value [32].

\subsubsection{Total fat and carbohydrate content.}

The total fat content in WBM (white button mushroom) was determined by Soxhlet Extraction technique. $109 \mathrm{~g}$ of the sample precisely weighed into the thimble and separated with the solvent in a Soxhlet extraction apparatus for approximately 16 hours. The concentrate was dried contained in the Soxhlet flask, whose vacant mass has been earlier determined at 95$100^{\circ} \mathrm{C}$ for 30 minutes. Continued drying and weighing were done alternately at 30 -minute intervals until the loss in mass between two consecutive weighings is not more than one milligram, and the lowest quantity was recorded and calculated [31]. 
The quantum of carbohydrate was determined after the percentage of moisture, protein, fat, and ash. Total carbohydrate calculated as:

$=100-(\mathrm{A}+B+C+D)$, where: $\mathrm{A}=$ percent by mass of moisture, $\mathrm{B}=$ percent by mass of total protein, $\mathrm{C}=$ percent by mass of fat, and $\mathrm{D}=$ total ash, percent by mass [34].

\subsubsection{Ash content and energy estimation.}

The content of ash in mushroom was determined by using Muffle Furnace. Weighed 3 $\mathrm{g}$ of the sample in the dish was weighed, which was previously dried in an air-oven and weighed. The plate was heated gently on a flame at first and then strongly in a muffle furnace till grey ash results, in the desiccator plate, cooled and further weighed. Inside the muffle furnace, the plate heated for 30 minutes. Thereafter, the plate kept in a desiccator, cooled, and weighed. The heating process repeated for 30 minutes, cooling and weighing were performed until the difference between two successive weighings is less than 1 milligram. Finally, the lowest quantity was recorded [29]. The energy value from the white button mushroom was calculated by the conversion method [33].

\subsection{White button mushroom categorization and storage.}

The white button mushroom was collected from mushroom houses at the Weikfield, Pune, and then segregated according to size, color, and veil opening. Thereafter, WBM samples were categorized into four groups; super quality Mushroom (SSQM), super quality Mushroom (SQM), A-grade, and B-grade. All categorized WBM placed into the polyethylene bags (thickness $30 \mu \mathrm{m}$ ) and stored under $5-6 \pm 1^{0} \mathrm{C}$ for eight days. All the experiments were performed at $0,2,4,6$, and 8 days.

\subsubsection{Assessment of WBM quality.}

A total of 20 packets of WBM contained, each bag carrying 200g WBM were selected and assessed for quality categorization. The quality categorization was divided into three categories, i.e., Sensory Evaluation, Physiochemical and bacteriological determination. All the test experiment was followed by standard methods.

\subsubsection{Whiteness.}

The colorimeter $\left(\mathrm{L}, \mathrm{a}^{*}, \mathrm{~b}^{*}\right)$ Model CR-400, Chroma Meter made by Konica Minolta company, Japan), was used for whiteness measurement. The chroma meter was standardized with a white plate before use. L*(lightness), $\mathrm{a}^{*}$ (+red-green), and $\mathrm{b}^{*}$ (+yellow-blue) parameters were measured on the side of the mushroom cap. A total of 10 samples from three replicate packages were measured. The hunter whiteness was calculated using the following formula: Hunter Whiteness $=\mathrm{L}-3 b^{*}[47]$.

\subsubsection{Size and grades.}

The harvested white button mushroom was segregated on the basis of the size of the cap. The size of the cap was measured by slide caliper and recorded in millimeters ( $\mathrm{mm}$ ). 


\subsubsection{Open veil.}

The below-mentioned formula was used to analyze the open the veil of WBM percentage [37].

$$
\% \text { Open Veils= }=\mathrm{N}_{\text {ov }} / \mathrm{Ntx} \text { X } 100
$$

Where Nt defines the total number of white button mushrooms, and $\mathrm{N}_{\mathrm{ov}}$ defines the number of open caps mushrooms.

\subsubsection{Texture, aroma (odour) and overall acceptance.}

The organoleptic evaluation was conducted by a trained panel for texture, aroma, and overall acceptability. 1-3 point hedonic rating test was used to evaluate the degree of acceptability of FWBM slice $5 \mathrm{~mm}$ from the sample. One slice from each sample of $5 \mathrm{~mm}$ thickness was provided to 10 panelists as randomly coded samples. The taste panelists were requested to rate the mushroom sample for their aroma, texture, and overall acceptability on a scale of 1-3 (where 3 represents the highest point; 2 represents a medium point, and 1 represents the lowest point) [18].

\subsubsection{Temperature.}

The samples of White Button Mushroom were kept under controlled temperature $6 \pm 1^{0} \mathrm{C}$ for days- $0,2,4,6$, and 8 . All test was conducted at room temperature.

\subsubsection{Moisture.}

The quantum of moisture percentage of the white button mushroom was determined by drying the fresh wet mushroom. They were kept at $105 \pm 2^{\circ} \mathrm{C}$ in an oven for 2 hours to dry. The weight of the sample was $5 \mathrm{gm}$ and place in the formerly dried and tared dish (dimensions 25 $\mathrm{mm}$ deep and $75 \mathrm{~mm}$ wide) and then transferred in an air oven. The dish was cooled in a desiccator, and weigh, and the process was repeated until the change between two consecutive weighings less than $1 \mathrm{mg}$. Finally, the lowest weight was recorded [29].

\subsubsection{Lactic acid.}

The quantum of lactic acid of white button mushroom was determined by the procedure described previously [29] and calculated as given below:

$$
\left.\frac{\left(\underline{\mathrm{M}_{2}-\mathrm{M}_{0}}\right)}{\mathrm{M}_{1}-\mathrm{M}_{0}} \times 100\right]+0.1 \alpha
$$

Where,

"Mo" denotes mass ( $\mathrm{g}$ ) of the dish (with zinc oxide), lid and stirring rod.

"M${ }_{1}$ " denotes the mass (g) of the dish (with zinc oxide), lid, stirring rod, and test portion.

"M2" denotes the mass (g) of the dish, lid stirring rod and dried test portion (including zinc oxide)

"a" denotes the mass (g) of lactic acid as achieved in Step I, and it is equal to $0.1 \mathrm{~g} / \mathrm{g}$ of lactic acid content. 


\subsubsection{Estimation of Lactococcus lactis.}

Initially, dilution of each sample was done by weighing the $10 \mathrm{~g} \mathrm{WBM}$ in a sterile environment and then placed into a sterile mortar and pastel with $90 \mathrm{ml}$ of the sterile buffer. The sample was homogenized and then serially diluted up to $10^{5}$ using the same diluent. Then, $0.1 \mathrm{ml}$ from each dilution was transferred into the MRS agar plate [23] $\left(30^{\circ} \mathrm{C} / 72 \mathrm{~h}\right)$ for Lacotococus lactis counts, and the colony counts were recorded.

\subsection{Statistical analysis.}

The quantum of nutrients and minerals contents of white button mushroom was presumed to be normal, and mean $\pm \mathrm{SD}$ were evaluated as representative parameters of the distribution. Statistical analysis was performed by SPSS [64] software by using two way ANOVA, and the $\mathrm{R}^{2}$ value was calculated.

\section{Results and Discussion}

Mushrooms are a noble source of vitamin B complexes such as riboflavin (B2), niacin (B3), Pantothenic acid (B5), ergosterols (provitamin D2) and minerals, i.e., selenium, potassium, and copper. Mushrooms additionally possess several therapeutic substances like triterpenoids, natural antibiotics, glycoproteins, enzymes, and enzyme inhibitors that strengthen the health system [12]. Zinc is a constituent of several enzyme systems that regulate various metabolic reactions. Mushrooms are considered a good source of zinc via a property of biological accumulator in nature [9].

This study is the first report for assessment of nutritional, medicinal, and quality categorization of FWBM (A. bisporus). In this study, nutrients, minerals elements, physicochemical factors evaluated for deterioration of the quality of white button mushroom. Our study showed that the various properties like whiteness, lactic acid, and Lactococcus lactis bacterial content in fresh white button mushroom dependent on various physicochemical factors. During the storage of WBM, the changes in these properties occur due to natural metabolic activity mushrooms. The nutrients and minerals contents of WBM is directly related compost on which they grow. The previous study also reported that heavy metals in white button mushrooms and compost were very significant and suitable for WBM cultivation and human consumption [61,62].

Normally the WBM were contains a very high natural source of protein, less in fats, carbohydrate, and no cholesterol. The high content of Fe, P, Ca, Mg, S, lactic acids, and Lactococcus lactis are very important components in FWBM, which controlled the biological activity. Consequently, designing standard methods by selecting discs from representative parts of the fruiting body, as well as discrimination between firmness and toughness, is important [46].In order to find out the precise nutritional composition and minerals content in white button mushrooms, were tested in Dr. Analytical laboratory, Navi Mumbai, India. The nutrients and minerals content indicated that composition in the fresh wet basis of a white button mushroom. The moisture, protein, fiber, and Energy (Kcal) contents of white button mushrooms were higher compare to previous study and lower ash, carbohydrate, and fat. The $\mathrm{R}^{2}$ value was found 0.997 , which is highly significant. The composition of this nutrient may be considered as potential nutraceuticals, and it can be beneficial for health-related issues and treatment of various kinds of diseases [3]. 


\subsection{Moisture.}

The moisture content in the fresh white button mushroom (FWBM) plays a very significant role in the quality of mushroom. In the present study, moisture ranged from 92.40$93.30 \%$. The average moisture content was $92.80 \pm 0.37 \%$ (Table 1), and the relationship between other nutrients found $\mathrm{R}^{2}=0.997$, which showed very significant (Fig. 1a).

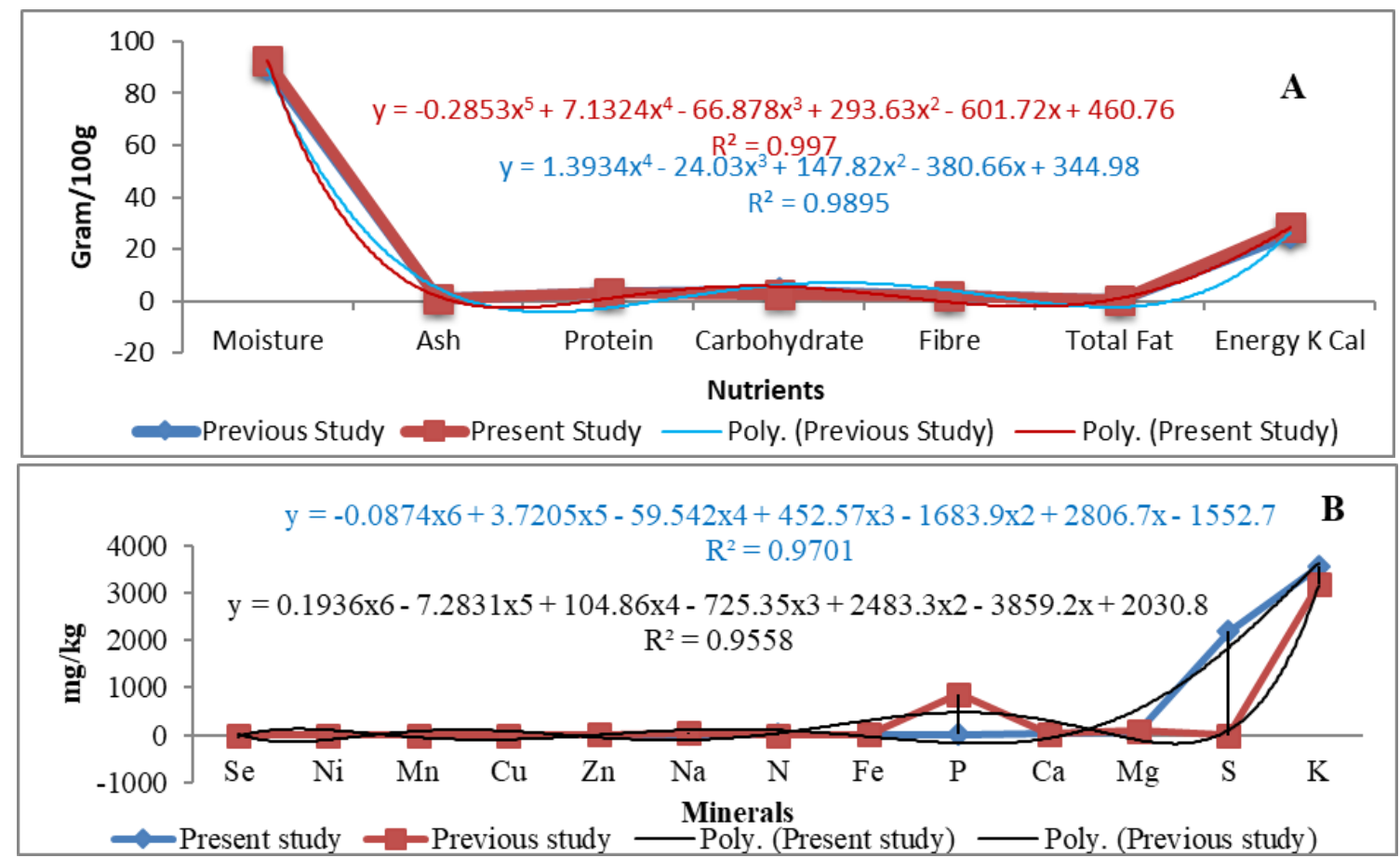

Figure 1. (A) Correlation of nutrients composition, Moisture, Ash, Protein, Carbohydrate, Fat, and Energy (KCal) (B) Correlation of minerals Se, Ni, Mn, Cu, Zn, Na, N, Fe, P, Ca, Mg, S, and K of Fresh White Button Mushroom. Each value represented as athematic mean \pm SD and statistically analyzed by SPSS 17 two way ANOVA and nutrients composition value $\mathrm{R}^{2}=0.997$ found more significant with respect to previous studies $\mathrm{R}^{2}=0.9895$. For minerals value, $R^{2}=0.9701$ also more significant compare to previous results $R^{2}=0.9558$.

\subsection{Proteins.}

The mushroom considered a good source of proteins that contained essential amino acids and substantial quantities of non-essential amino acids. The protein contents in mushrooms are varied due to the availability of nitrogen, geographical location, and also affected by environmental factors [13]. The results showed that protein content in FWBM was $3.27 \pm 0.12 \mathrm{~g} / 100 \mathrm{~g}$ [Table 1].

\subsection{Carbohydrate and fat.}

The mushrooms are an important natural source of carbohydrates. The Carbohydrate content was found to be lower than the quantum of protein in the mushrooms. The low carbohydrate content may be considered as a suitable food source for diabetic patients [42]. The mean quantum of carbohydrate in the fresh white button mushroom was $2.66 \pm 0.61$ (Table 1). The fats content in cultivated mushrooms had a lower amount compared to a wild variety [51] - The fat content in fresh white button mushroom was found to be $0.22 \pm 0.059$ (Table 1). 


\subsection{Energy and ash content.}

In natural mushrooms, which grow in forest contained an average of $1571.9 \mathrm{~kJ} / 100$ of dry weight basis compared to cultivated mushroom $1763.02 \mathrm{~kJ}$ found in a previous study [41]. The quantum of energy in the fresh white button mushroom was $28.50 \pm 1.22$ (Table 1). In this study, the Ash content in the fresh white button mushroom was found to be $0.93 \pm 0.01 \mathrm{~g} / 100 \mathrm{~g}$ (Table 1). Previous researchers reported ash content in mushroom $9.74 \mathrm{~g} / 100 \mathrm{~g}$ on a dry weight basis [11].

Table 1. Nutrients composition in fresh white button mushroom - gm/100gm.

\begin{tabular}{|c|c|c|c|c|c|c|c|c|}
\hline S.No & Moisture & Ash & Protein & Carbohydrate & Fiber & Total Fat & Energy $\mathrm{K} \mathrm{Cal}$ & References \\
\hline 1 & 89.5 & 1.25 & 3.94 & - & 1.09 & 0.19 & - & [7] \\
\hline 2 & 91.02 & 0.78 & 3.26 & 6.46 & - & 0.19 & 29.55 & [65] \\
\hline 3 & 91.39 & 1.074 & 2.75 & 2.36 & 3.36 & 0.448 & - & [49] \\
\hline 4 & 87.77 & 0.85 & 3.14 & 3.23 & - & 0.17 & - & [52] \\
\hline 5 & 92.45 & - & 3.09 & 3.26 & 1 & 0.34 & 22 & [16] \\
\hline Average & 90.43 & 0.99 & 3.24 & 3.83 & 1.82 & 0.27 & 25.78 & \multirow[t]{2}{*}{ Previous study } \\
\hline SD \pm & 1.63 & 0.19 & 0.39 & 1.56 & 1.09 & 0.11 & 3.78 & \\
\hline Sample1 & 92.40 & 0.92 & 3.12 & 3.41 & 1.95 & 0.16 & 27.00 & \multirow[t]{5}{*}{ Present study } \\
\hline Sample2 & 93.30 & 0.94 & 3.26 & 1.92 & 1.75 & 0.28 & 30.00 & \\
\hline Sample3 & 92.70 & 0.94 & 3.42 & 2.64 & 1.90 & 0.23 & 28.50 & \\
\hline Average & 92.80 & 0.93 & 3.27 & 2.66 & 1.87 & 0.22 & 28.50 & \\
\hline SD \pm & 0.37 & 0.01 & 0.12 & 0.61 & 0.08 & 0.05 & 1.22 & \\
\hline
\end{tabular}

3.5. Estimation of mineral content in Fresh white mushroom.

\subsubsection{Carbon.}

The carbon content in WBM (Agaricus bisporus) is considered an important factor in terms of its fruit body. The mean value of carbon content in FWBM was found to be $3.04 \pm 0.02 \%$. Still, the exact role of carbon content in fresh mushrooms is not yet reported.

Table 2. Minerals content in fresh white button mushroom-mg/kg.

\begin{tabular}{c|c|c|c|c|c|c|c|c|c|c|c|c|c} 
S.No & $\mathbf{S e}$ & $\mathbf{N i}$ & $\mathbf{M n}$ & $\mathbf{C u}$ & $\mathbf{Z n}$ & $\mathbf{N a}$ & $\mathbf{N}$ & $\mathbf{F e}$ & $\mathbf{P}$ & $\mathbf{C a}$ & $\mathbf{M g}$ & $\mathbf{S}$ & $\mathbf{K}$ \\
\hline Sample 1 & 0.05 & 0.05 & 0.47 & 2.67 & 3.85 & 2.6 & 4.9 & 13.61 & 19.8 & 20.61 & 64.36 & 87.78 & 3390 \\
\hline Sample 2 & 0.065 & 0.65 & 1.41 & 1.86 & 3.55 & 4.7 & 5.7 & 13.6 & 20 & 38.5 & 93.6 & 4304 & 3500 \\
\hline Sample 3 & 0.05 & 0.35 & 0.94 & 2.261 & 3.56 & 3.65 & 5.3 & 13.61 & 10.9 & 20.62 & 78.92 & 2195 & 3790 \\
\hline Average & $\mathbf{0 . 0 6}$ & $\mathbf{0 . 3 5}$ & $\mathbf{0 . 9 4}$ & $\mathbf{2 . 2 6}$ & $\mathbf{3 . 6 5}$ & $\mathbf{3 . 6 5}$ & $\mathbf{5 . 3 0}$ & $\mathbf{1 3 . 6 1}$ & $\mathbf{1 6 . 9 0}$ & $\mathbf{2 6 . 5 8}$ & $\mathbf{7 8 . 9 6}$ & 2195.59 & $\mathbf{3 5 6 0 . 0 0}$ \\
\hline SD \pm & 0.01 & 0.20 & 0.31 & 0.27 & 0.13 & 0.70 & 0.27 & 0.00 & 4.00 & 7.95 & 9.76 & 1405.60 & 153.33
\end{tabular}

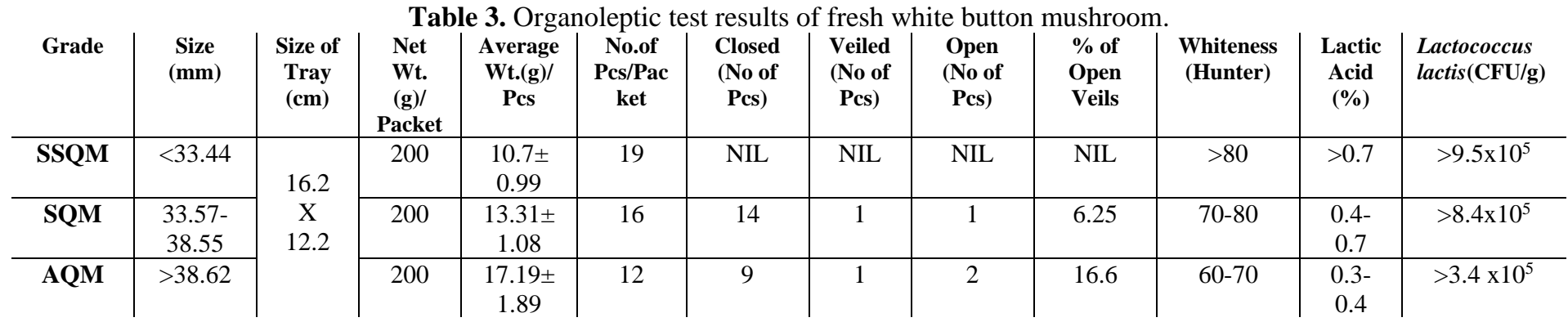




\subsubsection{Selenium.}

The selenium incorporated as a natural source into amino acids, such as selenocysteine and selenomethionine. The selenium content in the present study of FWBM was found to be $0.06 \pm 0.01 \mathrm{mg} / \mathrm{kg}$ (Table 2). Dietary consumption of selenium ranges from 7-4990 $\mu \mathrm{g}$ per day, with mean standards of $40 \mu \mathrm{g}$ every day in Europe and $93 \mu \mathrm{g}$ (in Ladies) to $134 \mu \mathrm{g}$ per day (in men) in the USA [54]. The WBMs is adequate to provide a sufficient amount in terms of everyday intake of selenium. The correlation coefficient of selenium with other minerals was very significant, and the $\mathrm{R}^{2}$ value of Se with other minerals was 0.9701 (Figure 2).
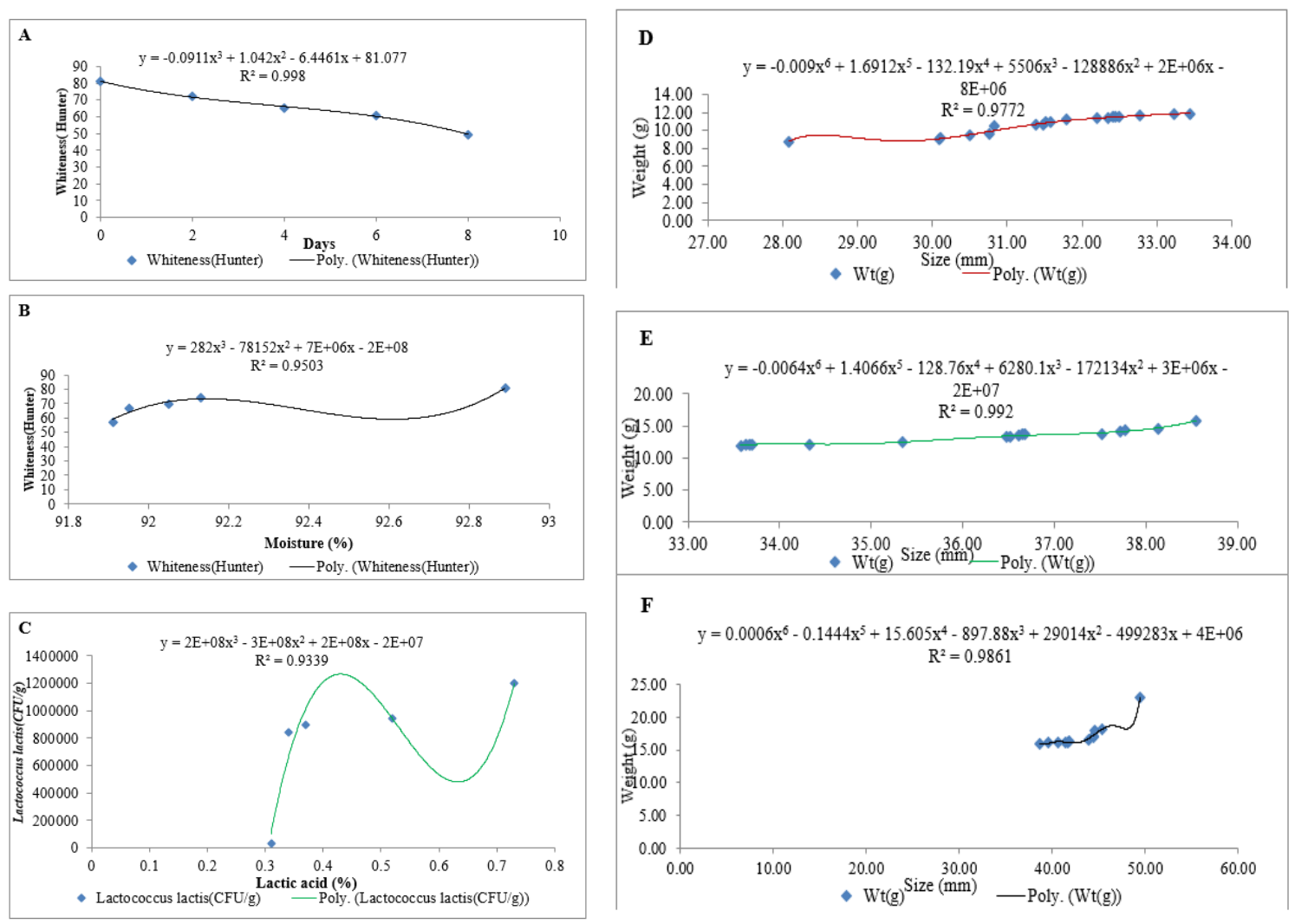

Figure 2. (A) Relationship between Whiteness (Hunter) and storage day of a white button mushroom. (B) Relationship between moisture content and whiteness of White button mushroom. (C) Relationship between Lactic acid and Lactococcus lactis bacteria in white button mushroom (D) Relationship between Length and WeightofWhite button mushroom Grade SSQM. (E) Relationship between Length and Weight of White Button Mushroom Grade SQM. (F) Relationship between length and weight of White Button Mushroom Grade AQM. Each value represented as arithmetic mean \pm SD and statistically analyzed by SPSS 17 One way ANOVA.Whiteness and Storage day value $R^{2}=0.998$, Moisture and Whiteness value of $R^{2}=0.9503$, Lactic acid and Lactococcus lactis value $\mathrm{R}^{2}=0.9339$, Length-weight grade $\mathrm{SSQM}$ value $\mathrm{R}^{2}=0.9772$, Length-weight grade SQM value $R^{2}=0.992$ and Length-weight grade $A Q M$ value $R^{2}=0.9861$ found to be significant.

\subsubsection{Nickel.}

Nickel may be considered as a stimulator of some enzyme systems, but at a higher level, its toxicity is also reported. It deposited in the lungs at high concentrations and may lead to bronchial hemorrhages or collapse [25]. Present study results showed that in FWBM, nickel content was found to be $0.35 \pm 0.20 \mathrm{mg} / \mathrm{kg}$ and varied between $0.05-0.65 \mathrm{mg} / \mathrm{kg}$ (Table 2). 


\subsubsection{Manganese.}

Manganese is a vital component of the mitochondrial oxidant scavenging enzyme, manganese superoxide dismutase. Manganese is also present in metalloproteins, such as pyruvate carboxylase, and in the cytoplasmic enzyme, glutamine synthesize. A deficiency of magnesium was shown to affect the humoral immune system. The average manganese content in fresh white button mushroom samples was $0.94 \pm 0.31 \mathrm{mg} / \mathrm{kg}$ (Table 2). The value for these mushroom species is in accordance with previously reported studies [35]. In plants, toxicity limits of manganese are high and range between $400-1000 \mathrm{mg} / \mathrm{kg}$ [75].

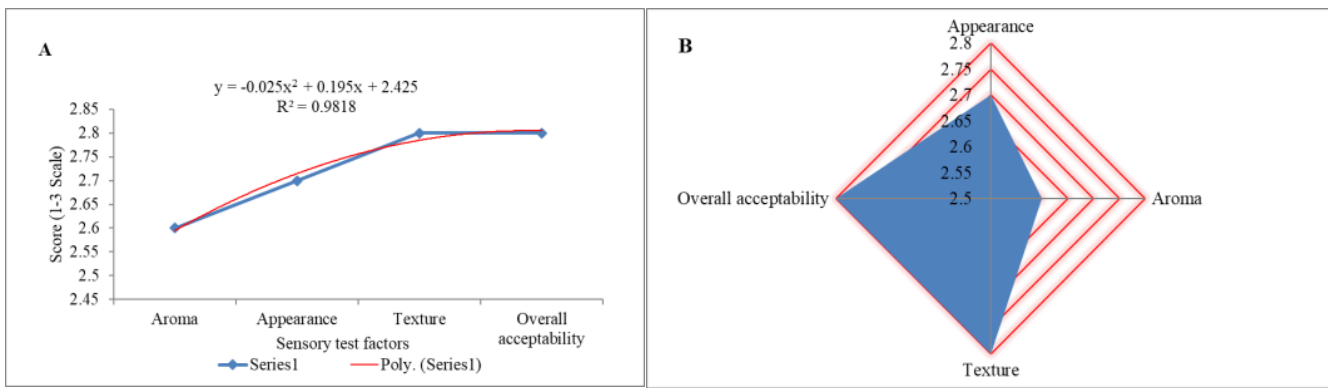

Figure 3. (A) Relationship of Sensory evaluation of white button mushroom. (B) Sensory evaluation score of a white button mushroom. Each value represented as athematic mean \pm SD and statistically analyzed by SPSS 17 One way ANOVA. Sensory relation of Aroma, Appearance, Texture, and overall acceptability value $\mathrm{R}^{2}=0.9818$ and sensory evaluation test by hedonic method value ranges.

\subsubsection{Copper.}

Copper is found to be the third most abundant trace element in the human body. The accumulation of copper suggests a possibility that the peptide or its digestive products show a vital part in the copper transport to the liver as a copper ligand. A small amount of copper is found in the human body $(50-120 \mathrm{mg}$ ), and it plays a very critical role in various biochemical processes [66,69]. The average copper content in the fresh white button mushroom was $2.26 \pm 0.27 \mathrm{mg} / \mathrm{kg}$ (Table 2). A.bisporus had the highest copper content accumulated in mushroom species, which is not considered as a health risk [40].

\subsubsection{Zinc.}

Related to adults, infants, babies, youngsters, teenagers, pregnant, and lactating ladies require zinc in an increased amount and, therefore, are at expanded risk of zinc reduction. Zinc paucity during the growing period results in growth let down. The deficiency of zinc, particularly in children, could results in appetite loss, weakness, growth retardation, low spirited, and retarded sexual growth [57]. The results of this study showed that the average $\mathrm{Zn}$ content present in WBM was $3.65 \pm 0.13$ and ranged between $3.55-3.85 \mathrm{mg} / \mathrm{kg}$ (Table 2).

\subsubsection{Sodium.}

Low sodium content in mushrooms is an ideal food for people having blood pressure. Previous reports in hypertensive patients (non-diabetic) have revealed that dietary modifications may reduce diastolic blood pressure if a low amount of sodium is included in daily diet [45]. Earlier research reported that sodium content in mushroom was $50 \mathrm{mg} / \mathrm{kg}$, while the present results showed that sodium content was $3.65 \pm 0.70 \mathrm{mg} / \mathrm{kg}$ and ranged between $2.6-$ $4.7 \mathrm{mg} / \mathrm{kg}$ (Table 2). 


\subsubsection{Nitrogen.}

Nitrogen is a very significant component of protein. The protein content of mushrooms relies on the structure of the substrate, size of the cap, harvesting time, and types of species [73]. Results indicated that a good natural source of nitrogen and revealed average nitrogen in FWBM was 5.30 \pm 0.27 and range between 4.9-5.7 mg/kg and (Table 2). The correlation coefficient $\mathrm{R}^{2}$ value of nitrogen with other minerals was 0.97 (Fig. 1b).

\subsubsection{Iron.}

Nutritional iron deficiency leads to a defect in thermoregulatory capacity in cold stress human as well as in model organisms. Iron deficiency also results in altered thyroid hormone metabolism throughout the estrous cycle [36]. The mean iron content present in the fresh WBM was $13.61 \mathrm{mg} / \mathrm{kg}$ (Table 2). The iron content in the present study is suitable for the human diet.

\subsubsection{Phosphorus and Calcium.}

Nutritional phosphorus and calcium consumption are often considered to be the main factors in bone mineralization and metabolism. Other research also has shown the potential for the treatment of osteoporosis by calcium intake and calcium supplementation [72]. The Calcium and Phosphorus were recorded an average phosphorus 16.90 \pm 4.0 , and calcium content was $26.58 \pm 7.95 \mathrm{mg} / \mathrm{kg}$ in the fresh white button.

\subsubsection{Magnesium.}

Magnesium helps to retain normal muscle, bone, and nerve function keeps heart rhythm steady, maintains a healthy immune system. In this study, average Magnesium content in fresh white button mushroom was found to be $78.96 \pm 9.76 \mathrm{mg} / \mathrm{kg}$ (Table 2). Magnesium is essential for mushrooms, and its uptake and sequestration are regulated by them [70].

\subsubsection{Sulfur.}

Mushroom contains L-Ergothioneine between 0.40 to $2.00 \mathrm{mg} / \mathrm{g}(\mathrm{D} / \mathrm{W})$, which is a type of sulfur-related amino acid. L-Ergothioneine can't be produced by humans inside the body. There was a significant increment in the ergothioneine substance of RBCs (mg/dL) with $16 \mathrm{~g}$ of mushroom powder (identical to 2 servings of fresh mushrooms) [74]. Sulfur carries out various functions in enzyme reactions and protein synthesis. It is a part of keratin, which is significant for the hair maintenance, skin, and nails, stimulating and shape to these protein tissues. It is also essential for collagen formation. Quantum of Sulphur in WBM samples was found to be $2195.59 \pm 1405.60$ (Table 2).

\subsubsection{Potassium.}

The high potassium content and the presence of bioactive compounds in the fruiting bodies could be associated with the neuronal stimulatory function. This may help in treatment options for patients with partially impaired cognitive functions. Prevention is preferred over treatment for this traumatic disease; once the signs of disease are clinically observable, the 
reversal is difficult [60]. The reported from the literature content of potassium in white button mushroom was $3180 \mathrm{mg} / \mathrm{kg}$ while present results showed $3560 \pm 153.33 \mathrm{mg} / \mathrm{kg}$ and varied between $3390-3790 \mathrm{mg} / \mathrm{kg}$ (Table 2). The white button mushroom may be considered as a potential candidate for the development of functional food to decrease/inhibit the intensity of age-related neurodegenerative diseases.

\subsection{Whiteness.}

Whiteness is one of the important quality parameters for white button mushroom, which has been evaluated by using the $L *$ lightness color value within the following range; $S S Q M>80$; SQM>70 and AQM-grade->60 (Table 3). It has also been observed that when the L value is less than 60, it was unacceptable for a supermarket. As shown in Fig.3 whiteness values of 0 to 6 days were reasonable range and acceptable for supermarket sale for eight days at $5-6 \pm 1^{0} \mathrm{C}$. The regression coefficient relationship between whiteness and storage day $R^{2}=0.998$ (Fig. 2a) as well as moisture and whiteness $\mathrm{R}^{2}=0.9503$ (Fig. 2b). After harvest, the white button mushroom color slowly changes from white color to brown, and this disapproving browning causes enzyme oxidation and bacterial growth, which results in damage to the nutritive value and shelf life of the mushroom $[2,5,38,43]$.

\subsection{Size and grades.}

The size of the button mushroom is categorized according to the diameter of and weight. The WBM categorically divided into three grades as per organoleptic, lactic acid, and Lactococcus lactis (Table 3). To make the accuracy of the grade length-weight relationship regression coefficient analyzed and found significant. The relationship regression coefficient was for SSQM grade $\mathrm{R}^{2}=0.9773$ (Fig. 2d), SQM grade $\mathrm{R}^{2}=0.992$ (Fig. 2e) and AQM grade $\mathrm{R}^{2}=0.9861$ (Fig. 2f).

\subsection{Open veil.}

The veil opening is unique of the utmost destructive post-harvest alteration in the white button mushrooms, which markedly influence the supermarket acceptability. The Veil opening percentage of the white button mushroom is interrelated with aging and water loss during the storage of the mushroom [33]. It was observed that increases in the veil opening of the white button mushroom up to $16.6 \%$ (Table 3). Veiled opening indicated that the white button mushroom becomes matured.

\subsection{Texture, aroma (odour), and overall acceptance.}

The supreme essential quality parameters with regards to consumer preferences are texture. After harvesting the loss of texture in white button mushroom is primarily accredited to the cell growth, lack of cuticle on the surface, moisture content, and water movement $[1,4$, 37]. The sensory evaluation was analyzed by 10 members of the panel, as shown in (Table 4). The mouthfeel attributes toughness (texture), appearance, aroma, and overall acceptability were correlated and found significant $\left(\mathrm{R}^{2}=0.981\right.$, Fig. 3a). Since the texture is a significant feature of keeping the quality of the mushroom, still, texture measurements during mushroom maturation, as well as during post-harvest storage, have been hindered by morphological/anatomical differences in the mushroom tissue occurring during development. 
The sensory evaluation also plotted by radar diagram and found overall acceptability of white button mushroom (Fig. 3b). Perishable fruiting bodies darken and change their taste and odor [71].

Table 4. Sensory evaluation of white button mushroom (Agaricus bisporus).

\begin{tabular}{l|c|c|c|c|c|c|c|c|c|c|c|c|c} 
Assessor & A & B & C & D & E & F & G & H & I & J & Total & Average & S.D \pm \\
\hline Appearance & 3 & 2 & 3 & 3 & 3 & 2 & 3 & 3 & 3 & 2 & 27 & 2.7 & 0.46 \\
\hline Aroma(Odour) & 3 & 3 & 2 & 2 & 3 & 3 & 3 & 2 & 2 & 3 & 26 & 2.6 & 0.49 \\
\hline Texture & 3 & 3 & 3 & 3 & 2 & 2 & 3 & 3 & 3 & 3 & 28 & 2.8 & 0.40 \\
\hline $\begin{array}{l}\text { Overall } \\
\text { acceptability }\end{array}$ & 3 & 2 & 2 & 3 & 3 & 3 & 3 & 3 & 3 & 3 & 28 & 2.8 & 0.40
\end{tabular}

\subsection{Temperature.}

The rate of spoilage of mushrooms depends on the temperature. The storage temperature of mushroom was kept at controlled conditions $5-6 \pm 1^{0} \mathrm{C}$ for eight days to minimize the metabolic activity $[22,50]$.

\subsection{Lactic acid and Lactococcus lactis.}

The content of lactic acid decreased with Lactococcus lactis bacteria. The average quantum of lactic acid was $0.454 \pm 0.156$ and Lactococcus lactis $\left(7.8 \times 10^{5} \pm 3.9 \times 10^{5}\right)$. The relationship between Lactic acid and Lactococcus lactis $\mathrm{R}^{2}=0.9339$ (Fig. 2c) was obtained and found significant. Lactic acid renders food unaffected to bacteriological spoilage, thus food with unique sensory qualities, and augments the health-improving properties of the product via enrichment of lactic acid bacteria and the presence of the viable, useful microflora. The essential component for the lactic fermentation procedure has mushroomed as the main ingredient $[30,56,67]$.

\section{Conclusions}

The present study on FWBM's nutritional, medicinal profile, and quality categorization has been made to utilize as nutraceuticals and therapeutic purposes. Our results indicated that FWBM has very high biological properties and contains nutrients and minerals components with good taste. This study also proposed that the consumption of white button mushrooms has important health benefits for the human body.

The order of minerals content for therapeutic and dietary values was in the order of $(\mathrm{Se}>\mathrm{Ni}>\mathrm{Mn}>\mathrm{Cu}>\mathrm{Zn}>\mathrm{Na}>\mathrm{N}>\mathrm{Fe}>\mathrm{P}>\mathrm{Ca}>\mathrm{Mg}>\mathrm{S}>\mathrm{K})$. This study could be beneficial in analyzing the quality parameters of fresh white button mushrooms within a temperature range of 5$6 \pm 1{ }^{\circ} \mathrm{C}$, which is acquired for conventional supply chains and, more precisely, during the commercial storage. This study results concluded that to harmonize the white button mushroom distribution and storage average temperature 5-6 $\pm 1{ }^{\circ} \mathrm{C}$, Moisture (\%) $92 \pm 0.36$, Whiteness (Hunter) 69.7 \pm 7.83 , Lactic acid (\%) $0.454 \pm 0.156$ and Lactococcus lactis $7.8 \times 105 \pm 3.94 \times 10^{5}$ $(\mathrm{CFU} / \mathrm{g})$ was suitable for good quality of mushroom. The beneficial health value of mushrooms due to the presence of lactic acid bacteria viable cells [63].

Future research is also required on chronic diseases and intake quantum of FWBM, especially with the rise of new proof of their medical advantage impacts. However, FWBM can be recommended for a daily diet to keep a sustainable life. 


\section{Funding}

This research work was supported by Excel College, Navi Mumbai, India, for scientific research in the area of white button mushroom nutritional, medicinal, and quality categorization.

\section{Acknowledgments}

I am grateful to Dr. Arun Mishra for providing financial support to conduct academic research at SGVU, Jaipur, and Rajasthan, India. I also thank the principal Prof. (Dr.) Sushil Kumar Sharma, Dr. Mukesh Kumar Gupta, and Management team of SGVU for continuous support and motivation.

\section{Conflicts of Interest}

The authors declare no potential conflict of interest.

\section{References}

1. Aguirre, L.; Frias, J.M.; Barry-Ryan, C.; Grogan, H. Assessing the effect of product variability on the management of the quality of mushrooms (Agaricus bisporus). Postharvest Biology and Technology 2008,49, 247-254, https://doi.org/10.1016/j.postharvbio.2008.01.014.

2. Akbarirad, H.; Kazemeini, S.M.; Shariaty, M.A. Deterioration and some of applied preservation techniques for common mushrooms (Agaricus bisporus, followed by Lentinus edodes, Pleurotus spp.). Journal of microbiology, biotechnology and food sciences 2019, 2398-2402.

3. Alarcon-Aguilara, F.J.; Roman-Ramos, R.; Perez-Gutierrez, S.; Aguilar-Contreras, A.; Contreras-Weber, C.C.; Flores-Saenz, J.L. Study of the anti-hyperglycemic effect of plants used as antidiabetics. Journal of ethnopharmacology 1998, 61, 101-110, https://doi.org/10.1016/S0378-8741(98)00020-8.

4. Antmann, G.; Ares, G.; Lema, P.; Lareo, C. Influence of modified atmosphere packaging on sensory quality of shiitake mushrooms. Postharvest biology and technology 2008,49,164-170, https://doi.org/10.1016/j.postharvbio.2008.01.020.

5. Ares, G.; Parentelli, C.; Gámbaro, A.; Lareo, C.; Lema, P. Sensory shelf life of shiitake mushrooms stored under passive modified atmosphere. Postharvest biology and technology 2006,41,191-197, https://doi.org/10.1016/j.postharvbio.2006.03.013.

6. Arumuganathan,T.; Rai, R.D.; Chandrasekar,V.; Hemakar, A.K. A studies on canning of button mushroom, Agaricus bisporus for improved quality. Mushroom Research 2004,12,117-120.

7. Bahl, N. Handbook on mushrooms. Fourth edition; CBS publishers and distributors Pvt Ltd: New Delhi,India, 2018, pp.14.

8. Baird, R.B.; Eaton, A.D.; Clesceri, APHA.American Public Health Association): Standard method for the examination of water and wastewater. Washington DC (US): AWWA (American Water Works Association) and WEF (Water Environment Federation 2012, 20, 141-142.

9. Bano, Z. Mineral and heavy metal contents in the sporophores of Pleurotus species. Mushroom Newsl. Trop 1981, 2, 3-6.

10. Barros, L.; Baptista, P.; Correia, D.M.; Morais , J.; Ferreira, I.C. Effects of conservation treatment and cooking on the chemical composition and antioxidant activity of Portuguese wild edible mushrooms. Journal of Agricultural and Food Chemistry 2007, 55, 4781-4788, https://doi.org/10.1021/jf070407o.

11. Barros, L.; Venturini, B.A.; Baptista, P.; Estevinho, L.M.; Ferreira, I.C. Chemical composition and biological properties of Portuguese wild mushrooms: a comprehensive study. Journal of agricultural and food chemistry 2008, 56, 3856-3862, https://doi.org/10.1021/jf8003114.

12. Beelman, R.B.; Royse, D.J.; Chikthimmah, N. Bioactive components in button mushroom Agaricus bisporus (J. Lge) Imbach (Agaricomycetideae) of nutritional, medicinal, and biological importance. International Journal of Medicinal Mushrooms 2003, 5, https://doi.org/10.1615/InterJMedicMush.v5.i4.10.

13. Beluhan, S.; Ranogajec, A. Chemical composition and non-volatile components of Croatian wild edible mushrooms. Food chemistry 2011, 124, 1076-1082, https://doi.org/10.1016/j.foodchem.2010.07.081.

14. Bernaś, E.; Jaworska, G. Vitamins profile as an indicator of the quality of frozen Agaricus bisporus mushrooms. Journal of Food Composition and Analysis 2016,49,1-8, https://doi.org/10.1016/j.jfca.2016.03.002. 
15. Bernaś,E.; Jaworska,G. Effect of preservation method on amino acid content in selected species of edible mushroom. LWT-Food Science and Technology 2012, 48, 242-247, https://doi.org/10.1016/j.lwt.2012.03.020.

16. Bhushan, A.; Kulshreshtha, M. The medicinal Mushroom Agaricus bisporus: Review of phytopharmacology and potential role in the treatment of various diseases. Journal of Nature and Science of Medicine $2018,1$.

17. Boa, E.R. Wild edible fungi: a global overview of their use and importance to people. Food and Agriculture Org 2004.

18. BSISO.Sensory analysis-Methods for assessing modification to the flavour of food stuffs due to packaging.2003, 13302,3-10.

19. Caglarlrmak, N.; Unal, K.; Otles, S. Determination of nutritive changes of canned mushrooms (Agaricus bisporus) during storage period. Micologia Aplicada International 2001, 13, 97-101.

20. Chang, S.T.; Miles, P.G. The nutritional attributes of edible mushrooms. Mushrooms: Cultivation, nutritional value, medicinal effect, and environmental impact. 2nd edition. Crc Press, Boca Raton, Fla 2004;pp. 27-37, https://doi.org/10.1201/9780203492086.ch2.

21. Chang, S.T. Overview of mushroom cultivation and utilization as functional foods. Mushrooms as functional foods 2008, 29, https://doi.org/10.1002/9780470367285.ch1.

22. Crisan, E.V.; Sands, A. Nutritive value. In:The biology and cultivation of edible mushroom.Chang,S.T.;Hayes,W.A. (Eds). New York, USA: Academic Press. Volume 1, 1978; pp. 137-168.

23. DeMan, J.C.; Rogosa, D.; Sharpe, M.E. A medium for the cultivation of lactobacilli. Journal of applied Bacteriology 1960, 23,130-135, https://doi.org/10.1111/j.1365-2672.1960.tb00188.x.

24. Deepalakshmi, K.; Sankaran, M. Pleurotus ostreatus: an oyster mushroom with nutritional and medicinal properties. Journal of Biochemical Technology 2014,5,718-726.

25. Demirbas, A. Heavy metal bioaccumulation by mushrooms from artificially fortified soils. Food chemistry 2001, 74, 293-301, https://doi.org/10.1016/S0308-8146(01)00155-8.

26. Didukh, M.; Nevo, E.;Volz, P.A. Impact of the ' family' Agaricaceae'(Fr.) cohn on nutrition and medicine. ARG Gantner 2004;pp. 205.

27. Dutta, R. Advances in Mushroom Science. Satish Serial Publishing House, Delhi Volume 14, 2007; pp. 240.

28. FCO. The Fertiliser (Control) Order, 1985 and the Essential Commodities Act, 1955.No, N. (1985). 11-3/83STU, Government of India, Ministry of Agriculture and Rural Development (Department of Agriculture and Cooperation), New Delhi 1985.

29. FSSAI. Manual of Methods of Analysis of Foods. Food Safety and Standard Authority of India. Ministry of Health and Family welfare. Government of India, New Delhi 2018;pp. 52-54.

30. Hutkins, R.W. Microbiology and technology of fermented foods. John Wiley \& Sons2008, 22, https://doi.org/10.1002/9780470277515.

31. IS.Testingand Inspection for Certification of Edible Groundnut Flour (Expeller Pressed).Government of India, Buero of Indian standards RA 2015, 4684, 1975.

32. IS.Specification for Edible Ground nut floor Expeller pressed 1975, Bureau of Indian Standards, Govt.of India RA 2015, 4684, 9-11

33. IS. Milk cereal based complementary foods specification. Bureau of Indian Standards, Govt. of India, Manak Bhavan, 9, Bahadur Shah ZafarMarg, New delhi-110002 RA 2018, 1656, 1-6.

34. Isildak, Ö.; Turkekul, I.; Elmastas, M.; Tuzen, M. Analysis of heavy metals in some wild-grown edible mushrooms from the middle black sea region 2004, 86, 547-52, https://doi.org/10.1016/j.foodchem.2003.09.007.

35. Işıloğlu, M.;Yılmaz, F.; Merdivan, M. Concentrations of trace elements in wild edible mushrooms. Food Chemistry 2001,73,169-175, https://doi.org/10.1016/S0308-8146(00)00257-0.

36. Jiang, T.; Zheng, X.Li, J.; Jing, G.; Cai, L.; Ying, T. Integrated application of nitric oxide and modified atmosphere packaging to improve quality retention of button mushroom (Agaricus bisporus). Food Chemistry 2011, 126, 1693-1699, https://doi.org/10.1016/j.foodchem.2010.12.060.

37. Jolivet, S.; Arpin, N.; Wichers, H.J.; Pellon, G. Agaricus bisporus browning: a review. Mycological Research 1998,102,1459-83, https://doi.org/10.1017/S0953756298006248.

38. Kadnikova, I.A.; Costa, R.; Kalenik,T.K.; Guruleva, O.N; Yanguo, S. Chemical composition and nutritional value of the mushroom Auricularia auricula-judae. Journal of Food and Nutrition Research 2015, 3, 478$82 .$.

39. Kalac, P.; Svoboda, L. A Review of trace element concentrations in edible mushrooms. Food chemistry2000, 69, 273-81, https://doi.org/10.1016/S0308-8146(99)00264-2.

40. Kalac, P. Chemical composition and nutritional value of European species of wild growing mushrooms: A review. Food chemistry2009, 113, 9-16, https://doi.org/10.1016/j.foodchem.2008.07.077.

41. Kubo, K.; Nanba, H. Anti-diabetic mechanism of maitake (Grifola frondosa). In: Mushroom Biology and Mushroom Products. Royse, D.J. ed. University Park, PA: Penn State University 1996;pp. 215-221.

42. Lagnika, C.; Zhang, M.; Wang, S. Effect of high argon pressure and modified atmosphere packaging on the white mushroom (Agaricus bisporus) physico-chemical and microbiological properties. Journal of Food \& Nutrition Research 2011, 50, 167-176. 
43. Latimer, G.W.; Horwitz, W. Official methods of analysis. Association of Official Analytical Chemists (AOAC) International, 20 thEd. Canada: AOAC 2016.

44. Macgregor, G.; Best, F.; Cam, J.; Markandu, N.; Elder, D.; Sagnella, G.; Squires, M. Double-blind randomised crossover trial of moderate sodium restriction in essential hypertension. The Lancet 1982, 319,351-5, https://doi.org/10.1016/S0140-6736(82)91389-7.

45. McGarry, A.B.; Burton, K.S. Mechanical properties of the mushroom, Agaricus bisporus.Mycological research 1994, 98, 241-245, https://doi.org/10.1016/S0953-7562(09)80192-5.

46. Minolta, K. Chromameter CR-400/410 Instruction Manual. Konica Minolta Sensing Inc.,Osaka, Japan 2007.

47. Muyanja, C.; Kyambadde, D.; Namugumya, B. Effect of Pretreatments and Drying Methods on Chemical Composition and Sensory Evaluation of Oyster Mushroom (Pluerotus Oestreatus) Powder and Soup. Journal of Food Processing and Preservation 2014,38,457-65, https://doi.org/10.1111/j.17454549.2012.00794.x.

48. Nasiri, F.; Tarzi, B.G.; Bassiri, A.; Hoseini, S.E. Comparative study on some chemical compounds of button mushrooms (Agaricus bisporus) cap and stipe during the first to third flushes. Ann Biol Res.2012, 3, 56775680 .

49. Oliveira, F.; Sousa-Gallagher, M.J.; Mahajan, P.V.; Teixeira, J.A. Development of shelf-life kinetic model for modified atmosphere packaging of fresh sliced mushrooms. Journal of Food Engineering 2012, 111, 466-73, https://doi.org/10.1016/j.jfoodeng.2012.01.013.

50. Ouzouni, P.; Riganakos, K. Nutritional value and metal content profile of Greek wild edible fungi. Acta Alimentaria 2007, 36, 99-110, https://doi.org/10.1556/aalim.36.2007.1.11.

51. Poongkodi, G.K.; Harithra Priya, G.P.; Harshitha Priya, G.P. Nutrient contents of edible mushrooms.Agaricus bisporus and Pleurotus ostreatus. Int J Mod Chem Appl Sci. 2015, 2, 78-86.

52. Rai, R.D.; Arumuganathan, T. Post harvest technology of mushrooms. Chambaghat, India: National Research Centre for Mushroom, Indian Council of Agricultural Research 2008, 1-29.

53. Rayman, M.P. Food-chain selenium and human health: emphasis on intake. British journal of nutrition 2008, 100, 254-68, https://doi.org/10.1017/S0007114508939830.

54. Reis, F.S.; Martins, A.; Barros, L.; Ferreira, I.C. Antioxidant properties and phenolic profile of the most widely appreciated cultivated mushrooms: A comparative study between in vivo and in vitro samples. Food and Chemical Toxicology 2012, 50, 1201-1207, https://doi.org/10.1016/j.fct.2012.02.013.

55. Rhee, S.J.; Lee, J.E.; Lee, C.H. Importance of lactic acid bacteria in Asian fermented foods. Microbial Cell Factories.BioMed Central 2011, 10, 1-5, https://doi.org/10.1186/1475-2859-10-S1-S5.

56. Roohani, N.; Hurrell,R.;Kelishadi, R.; Schulin, R. Zinc and its importance for human health: An integrative review.The official journal of Isfahan University of Medical Sciences 2013, 18, 144.

57. Rosli,W.W.; Aishah, M.S. Pleurotus sajor-caju (PSC) improves nutrient contents and maintains sensory properties of carbohydrate-based products. International Journal of Nutrition and Food Engineering 2012, 6, 87-9, https://doi.org/10.5281/zenodo.1077171.

58. Rosli,W.I.W.; Maihiza, N.; Raushan, M. The ability of oyster mushroom in improving nutritional composition, $\beta$-glucan and textural properties of chicken frankfurter. International Food Research Journal 2015, 22, 311-317.

59. Sabaratnam,V.; Kah-Hui,W.; Naidu, M.; David, P.R. Neuronal health-can culinary and medicinal mushrooms help?. Journal of Traditional and Complementary Medicine 2013, 3, 62-8, https://doi.org/10.4103/2225-4110.106549.

60. Sinha, S.K.; Upadhyay, T.K.; Sharma, S.K. Heavy metals detection in white button mushroom (Agaricus bisporus) cultivated in state of Maharashtra, India. Biochemical and Cellular Archives 2019, 19, 3501-3506.

61. Sinha, S.K.; Upadhyay, T.K.; Sharma, S.K. Nutritional assessment of compost by SMC method for white button mushroom cultivation in Maharashtra. African Journal of Biological Sciences2020, 2, 16-24, https://doi.org/10.33472/AFJBS.2.2.2020.16-24.

62. Skapska, S.; Owczarek, L.; Jasinska, U.; Halasinska, A.; Danielczuk, J.; Sokolowska, B.; RolnoSpozywczego, I.B. Changes in the antioxidant capacity of edible mushrooms during lactic acid fermentation. Zywnosc Nauka Technologia Jakosc (Poland) 2008, 4, 243-250.

63. SPSS.For windows step by step: A simple study guide and reference. 17.0 update, 10/e. Pearson Education India, 2011.

64. Stamets, P.E. Notes on nutritional properties of culinary medicinal mushrooms.International Journal of Medicinal Mushrooms 2005, 7,103-110, https://doi.org/10.1615/IntJMedMushr.v7.i12.100.

65. Steinkraus, K.H. Fermentations in world food processing. Comprehensive Reviews in Food Science and Food Safety 2002, 1, 23-32, https://doi.org/10.1111/j.1541-4337.2002.tb00004.x.

66. Strain, J.J. Newer aspects of micronutrients in chronic disease: copper.Proceedings of the Nutrition Society1994, 53, 583-98, https://doi.org/10.1079/PNS19940067.

67. Teklit, G.A. Chemical composition and nutritional value of the most widely used mushrooms cultivated in Mekelle Tigray Ethiopia. Journal of Nutrition \& Food Sciences 2015, 5, 1-3, https://doi.org/10.4172/21559600.1000408 . 
68. Tseng,Y.H.; Mau, J.L. Contents of sugars, free amino acids and free 5 ' nucleotides in mushrooms, Agaricus bisporus, during post-harvest storage. Journal of the Science of Food and Agriculture 1999, 79, 1519-1523, https://doi.org//10.1002/(SICI)1097-0010(199908)79.

69. Vetter, J. Chemical composition of fresh and conserved Agaricus bisporus mushroom. European Food Research and Technology 2003, 217, 10-12, https://doi.org/10.1007/s00217-003-0707-2.

70. Vetter, J. Phosphorus content of edible wild mushrooms of Hungary. Acta alimentaria (Budapest) 1994, 23, 331-316.

71. Wani, B.A.; Bodha, R.H.; Wani, A.H. Nutritional and medicinal importance of mushrooms. Journal of Medicinal Plants Research 2010, 4, 2598-2604, https://doi.org/10.5897/JMPR09.565.

72. Weigand, A.J. The Bioavailability of Ergothioneine from Mushrooms and the Acute Effects on Antioxidant Capacity and Biomarkers of Inflammation in Human Participants.The PennsylvaniaState University 2012, 54, 75-78, https://doi.org/10.1016/j.ypmed.2011.12.028.

73. Wiafe-Kwagyan, M.; Obodai, M.; Odamtten, G.T.; Kortei, N.K. The potential use of rice waste lignocellulose and its amendments as substrate for the cultivation of Pleurotus eous Strain P-31in Ghana.IJAPBC 2016, 5, 116-130.

74. Zadražil, F. Influence of ammonium nitrate and organic supplements on the yield of Pleurotus sajor caju (Fr.) sing. European journal of applied microbiology and biotechnology 1980, 9, 31-35, https://doi.org/10.1007/BF00499999.

75. Zhou, L.Y.; Li, W.; Pan, W.J.; Sajid, H.; Wang, Y.; Guo, W.Q.; Cai, Z.N.; Wang, D.D.; Yang, W.W.; Chen, Y. Effects of thermal processing on nutritional characteristics and non-volatile flavor components from Tricholoma lobayense. Emirates Journal of Food and Agriculture 2017, 285-292, https://doi.org/10.9755/ejfa.2016-12-1815. 